\title{
Students' Perception of Speech Method toward the University Students' Speaking Skill
}

\author{
Ayu Wulandari \\ Universitas Airlangga, Surabaya \\ *Corresponding email: stevaniwulandari100296@gmail.com
}

Naskah diterima: 30 Maret 2021 | Disetujui: 28 April 2021 | Diterbitkan: 25 Mei 2021

\begin{abstract}
The Speech Method implementation is considered an excellent way to improve the university students' speaking skills. By delivering a Speech in front of many people, students are expected to have better speaking skills. This study was conducted using a descriptive qualitative research design to investigate and perceive students' perception of the speech method. The researcher took 12 students as the participants who joined the Speaking IV class. Using a questionnaire and interview as methods to collect the factual data, the researcher concluded that the existence of the Speech Method could improve students' speaking skills-it skills proven by $93 \%$ of respondent who agrees on it. Unfortunately, some difficulties were getting by getting students. One is that there were not feel nervous in delivering their Speech and have limited vocabulary that makes them unable to English fluently in front of the audience. However, the students perceived that the Speech Method's existence improved students' speaking skills. However, students still need more challenges like getting more presentations on having Speech to learn English fluently.
\end{abstract}

Keywords: Perception, Speech, Method, speaking skill, student.

\begin{abstract}
Abstrak
Penerapan metode pidato dianggap sebagai sebuah cara baik untuk meningkatkan kemampuan berbahasanya mahasiswa. Dengan menyampaikan pidato di depan banyak orang, mahasiswa diharapkan memiliki kemampuan berbahasa yang lebih baik. Penelitian ini diadakan dengan menggunakan penilitian deskriptif kualitatif untuk meneliti dan mendapatkan persepsi mahasiswa tentang metode pidato. Peneliti menggunakan 12 mahasiswa sebagai peserta yang sekaligus mengikuti mata kuliah Speaking IV. Peneliti menggunakan kuesioner dan wawancara sebagai teknik pengambilan data yang konkrit, kesimpulan yang dapat diambil bahwa adanya penggunaan metode pidato dapat meningkatkan kemampuan berbahasa bagi mahasiswa. Hal tersebut dibuktikan oleh 93\% peserta yang setuju terhadap pendapat tersebut. Sayangnya, terdapat beberapa kesulitan yang didapatkan oleh mahasiswa, salah satu diantaranya adalah banyak mahasiswa yang merasa gugup disaat mesampaikan pidatonya dan mereka juga memiliki keterbatasan kosa kata yang membuat mereka tidak dapat berbahasa inggris dengan lancer di depan penonton. Meski begitu, para mahasiswa menganggap bahwa adanya metode pidato dapat meningkatkan kemampuan berbahasa mahasiswa teteapi mahasiswa masih membutuhkan tantangan lebih lain seperti mendapatkan latihan yang lebih banyak untuk berpidato sehingga mereka dapat belajar berbahasa Inggris dengan lancar.
\end{abstract}

Kata kunci: Persepsi, pidato, metode, kemampuan berbahasa, mahasiswa. 


\section{Introduction}

Speaking skill is essential for students. A language is a communication tool; without communication, people will be challenging to express and show their ideas. So, language is essential to be learned by everyone. Today, everyone must be able to speak English well because some people use English in various situations. The guide who wants to pick the tourist up at the airport needs an English to get a successful activity. A secretary who does the job on the Laptop needs an understanding of English to operate the Laptop well. Some people who buy the technologies also need English to know how to use the technology by reading the instruction book.

Speaking is also known as an interactive process of constructing meaning that involves producing, receiving, and processing information (Burns \& Joyce, 1997). To have good speaking skills, students should be knowledgeable and prosperous on the vocabularies. Speaking has been becoming an excellent way to improve English proficiency, but most students say that it is complicated to express ideas in which they do not know how to speak well and fluently precisely when they have to make Speech.

Nowadays, Mastering many languages is wanted by everybody, especially English as an international language. English is taught at many levels of education in Indonesia. Mastering speaking English, there are many ways to be done, such as listening to music, reading English books, and one of the most exciting methods done by one of the English education departments at the University of Banyuwangi, namely speech method.

Speech Class is a way to improve the students' speaking skills in the Speaking IV at the University of Banyuwangi. The lectures have been becoming a method since Speaking IV was taught in the English Educational Department of the University of Banyuwangi to make the students speak up fluently. Without practicing how to speak English well, the students will not be able to do it. In the speech class, the lecturer teaches the student to be a confident person who has to act like a native speaker with time limitations. Surprisingly, for the students who can deliver their speeches in more than 4 minutes, the teacher will give them better scores because the role of speech class is to make the students speak English fluently and enrich some vocabularies. Nevertheless, even the students are forced to speak English fluently, but it also teaches them to implement grammar and structure in their Speech. So they can arrange their words into good sentences.

The Faculty of Language and Art is one of the sixth faculties in the University of Banyuwangi. The curriculums offered to the students in the learning process at the English Educational Department include sixty-five subjects, one of which is Speaking IV (88203035 A - 3 credits). Speaking IV is the constitutional of Speaking I (88203024 A - 3 credits), speaking II (88203035 A- 3 credits), and speaking III ( $88203044 \mathrm{~A}-3$ credits) and the students can pass these subjects by score $\mathrm{C}$ as the minimum score.

Academically, students of the English Educational Department have been required to be in the sixth semester, meaning they have passed 45 subjects. The students who are taking Speaking IV might be called a group of Speech Class and if they can reach a good score in the speech presentation, they are considered better speakers who do not have obstacles in speaking skills.

Based on the explanation above, the researcher conducted this study to investigate and perceive the students' perception of the implementation of the speech method in improving the sixth-semester students' speaking skills in Banyuwangi. 


\section{Research Design}

Research design is a procedure in planning research that is helpful as a guide to build a strategy that results in the research model. The design used in this research is descriptive qualitative research. According to (Suryana, 2010) the aims of conducting a descriptive study are to make a description systematically, factually and accurately about facts and characteristics of a particular population. A descriptive study can provide information about the naturally occurring health status, behavior, attitudes, or other characteristics of a particular group. Besides, the goal of qualitative descriptive studies is a comprehensive summarization, in simple terms, of specific events experienced by individuals or groups of individuals. So, this researcher was finding the students' perception of speech method with descriptive studies toward the Sixth Semester Students' Speaking Skill at the English Educational Department at the University of Banyuwangi in the 2016/2017 Academic year.

\section{Finding and Discussion}

The students' questionnaires and interview results were given accordingly to two main themes related to students' perception of a speech method in the Speaking IV towards their speaking skill.

\section{Students' perception of a speech method}

All of the students believed that Speech could improve their speaking skills and confidence to speak in front of many people. Besides, few respondents said that the teaching-learning process in Speaking Class did not improve their SpeakingSpeaking to be in a good fluency. Therefore, the questionnaires and interviews enabled the students to convey their judgments about a speech method as elaborated below.

\section{The Results of Questionnaires}

The questionnaires distributed to 12 students had nine statements related to the speech method and six statements related to the influence of a speech method on students' speaking skills. The purpose of the questionnaires was to find out how they thought about the existence of a speech method, especially in the speaking IV. The responses to every statement were very various as mentioned in the following. (See appendix F, Recapitulation of Questionnaires Result, to see the complete table of responses).

Statement 1 was about the importance of a speech method. Twelve (12) students or 100\% answered "YES".

Statement 2 was about whether the students know what a speech method is. Twelve (12) students or $100 \%$ answered "YES".

Statement 3 was about whether the students attended to the speech method. Twelve (12) students or $100 \%$ answered "YES".

Statement 4 was about whether they like a speech method. Eight (8) of twelve (12) students or $67 \%$ answered "YES", while four (4) out of twelve (12) or 33\% answered "NO". 
Statement 5 was about whether they participate in the speech method well. Six (6) of twelve (12) students answered "YES", while six (6) out of twelve (12) answer "NO"

Statement 6 was about whether the lecturer of a speech method taught the students very well. Eleven (11) of twelve (12) students or 92\% answered "YES", while eight (8) out of twelve (12) students or $8 \%$ answered "NO".

Statement 7 was about whether a speech method had a short time to deliver the material within a semester. Eight (8) of twelve (12) students or 67\% answered "YES", while four (4) out of twelve (12) students or $33 \%$ answered "NO".

Statement 8 was about whether the student was satisfied with the time allocated in delivering the Speech in front of the class. Nine (9) of twelve (12) students or 75\% answered "YES", while three (3) out of twelve (12) students or $25 \%$ answered "NO".

Statement 9 was about whether the student requested the speech method given in every semester. Eight (8) of twelve (12) students or 67\% answered "YES", while four (4) out of twelve (12) answered "NO".

\section{The Results of the Interview}

Question 1 was what they thought about the existence of a speech method in speaking IV. Nine (9) respondents answered that a speech method was good for them because they were forced to speak up that could increase their vocabularies and made them feel more confident. Two (2) of them said they liked a speech method, but they just did not like the technique used by the teacher of a speech method that always focused on the material. One (1) of them said he did not like a speech method because he did not like speaking. These three main themes of their answered are presented below.

"I think the existence of a speech method is good for us because we are taught how to speak fluently and it increases my vocabularies also makes me feel more confident."

"I think in this speech method there is no something special because the material is monotonous."

" I do not like a speech method because I am difficult to speak English."

Question 2 was about how the teacher of a speech method taught them in speaking IV. The answers to this question were almost different for each student as presented in the following table.

Table 2. Classification of Interview

\begin{tabular}{|l|l|l|}
\hline \multicolumn{2}{|l|}{ Question: How does the lecturer teach the speech method in speaking IV? } \\
\hline No & Respondents & Answer \\
\hline 1 & AUM & $\begin{array}{l}\text { "He is nice, but I need him to do some examples before he } \\
\text { asked me to deliver my speech in front of the class." }\end{array}$ \\
\hline 2 & AD & $\begin{array}{l}\text { "It is fun; we are taught to speak and write the text of Speech. } \\
\text { So, one day if I become a successful person I can deliver my } \\
\text { Speech easily." }\end{array}$ \\
\hline
\end{tabular}




\begin{tabular}{|c|c|c|}
\hline 3 & DEDE & $\begin{array}{l}\text { "He is nice, he always asks us to practice but sometimes I do } \\
\text { not understand his saying that it is too fast and focus on the } \\
\text { material only." }\end{array}$ \\
\hline 4 & DWL & $\begin{array}{l}\text { "He does not have a good way to explain the material. } \\
\text { Sometimes, some of us do not understand what he's saying" }\end{array}$ \\
\hline 5 & GP & $\begin{array}{l}\text { "He is good at teaching the students and he makes me } \\
\text { understand the material easily." }\end{array}$ \\
\hline 6 & ITH & $\begin{array}{l}\text { "the teacher of this a speech method has good manner where } \\
\text { after he explains the material he asks us to get practicum and } \\
\text { he always asks the student who cannot deliver the speech } \\
\text { well to repeat the practicum until he can speak fluently." }\end{array}$ \\
\hline 7 & NA & $\begin{array}{l}\text { "He is a boring teacher, and he gives us a short time to } \\
\text { deliver the Speech. Also, he always gives us more videos } \\
\text { than practicum." }\end{array}$ \\
\hline 8 & NHDN & $\begin{array}{l}\text { "He is a boring teacher because he always speaks English. } \\
\text { There is no intermezzo and jokes. He always focuses on the } \\
\text { video of a native speaker." }\end{array}$ \\
\hline 9 & NIA & $\begin{array}{l}\text { "I think he makes me feel sleepy because he is too much } \\
\text { explanation." }\end{array}$ \\
\hline 10 & $\mathrm{SH}$ & $\begin{array}{l}\text { "He is a little bit boring, and he cannot make the class } \\
\text { attractive." }\end{array}$ \\
\hline 11 & $\mathrm{TW}$ & $\begin{array}{l}\text { "I like the way he teaches us, he always teaches us clearly } \\
\text { and he always welcomes the students." }\end{array}$ \\
\hline 12 & $\mathrm{ZH}$ & $\begin{array}{l}\text { He is a bit boring in teaching the speech method because he } \\
\text { always focuses on his presentation slides. }\end{array}$ \\
\hline
\end{tabular}

Question 3 was about whether they enjoyed the speech method. Six (6) respondents answered they did not enjoy the class because the teaching-learning process was tedious. One (1) respondent answered that she did not enjoy the speech method because she did not have intended to get a lecture. Five (5) respondents answered that they enjoyed the class for a different reason. These seven main themes of their answered are presented below.

"I do not enjoy the speech method because it is a boring class. There is no more practicum in this A speech method and the teacher is too serious in teaching the speech method."

" No, I do not, because I take a course in this department is caused by my parents."

"YES, I do; I enjoy this speech method. Moreover, it teaches me to speak fluently for my future if I become a successful person."

"YES, sometimes, because sometimes the teacher of this speech is good at explaining the material and sometimes he is a boring teacher." 
"YES, because it is an interesting class in speaking IV, but sometimes the teacher of a speech method teaches us seriously."

"YES, I enjoy this speech method because in this lecture, there is no homework."

"YES, I enjoy a speech method because I like speaking."

Question 4 was about whether they had difficulties in delivering the Speech. Nine (9) respondents said, "YES, I have, am not confident to speak in front of the audiences and I still have low vocabularies also sometimes cannot speak without bringing the text", two (2) respondents answered, "I do not have difficulties in a speech method".

\section{The Influence of a Speech Method on Students' Speaking Skill}

The existence of a speech method in speaking IV is to increase students' speaking skills. Here are presented how many students get the influence of a speech method toward their speaking skill according to the questionnaires and interview responses.

The Questionnaires:

The statements given in the questionnaires related to the students' perception due to a speech method influence toward students' speaking skill were six (6) statements. The purpose was to find out whether a speech method influenced the students' speaking skills. The answered was likely and about to the same for each respondent, though some of them gave various perceptions as explained in the following.

Statement 1 was about whether a speech method improved their speaking skill. Twelve (12) respondents, or $100 \%$, chose "YES".

Statement 2 was if whether the material of a speech method trained them to speak up. Nine (9) of them, or 75\% answered "YES," while three (3) out of twelve (12) answered "NO".

Statement 3 was about whether they got success in delivering the Speech in front of the class. Four (4) respondents, or 33\% answered "YES". Eight (8) respondents out of twelve (12) respondents or $67 \%$ answered "NO".

Statement 4 was about whether they got difficulties in delivering Speech in front of the audience. Eight (8) respondents or 67\% answered "YES" while four (4) respondents or $33 \%$ answered "NO".

Statement 5 was if their SpeakingSpeaking was not good before joining the speech method. Eleven (11) respondents or $92 \%$ answered "YES". While one (1) respondent out of twelve (12) or 8\% answered "NO."

Statement 6 was if a speech method was one of the best ways to improve students' speaking skills. Eleven (11) respondents, or 92\%, answered "YES." While one (1) respondent out of twelve (12) or $8 \%$ answered "NO."

The Interview:

There were two questions related to the influence of a speech method on students' speaking skills. The answers of each respondent were various, as mentioned below. 
Question 1 was about whether the existence of a speech method improved their speaking skill. Eleven (11) respondents answered the same response. One (1) respondent had another opinion about this. These two main themes of their answered are presented below.

"YES, it improves my speaking skill and forces me to speak up."

"YES, it improves my speaking skill, but I am lazy to increase my vocabulary."

Question 2 was about students' suggestions for the speech method in the future. The answers to this question were almost different for each student, as presented in the following table.

Table 3. The Answer for Question 2

\begin{tabular}{|c|c|c|}
\hline \multicolumn{3}{|c|}{ Question: Do you have a suggestion for a speech method in the future? } \\
\hline No & Respondents & Answer \\
\hline 1 & AUM & $\begin{array}{l}\text { "I think a speech method in the next future must focus on the } \\
\text { practicum, and the teacher should give the specific topic to } \\
\text { us in order the students can think easily asked me to deliver } \\
\text { my speech in front of the class." }\end{array}$ \\
\hline 2 & $\mathrm{AD}$ & $\begin{array}{l}\text { "I think for the next speech method, the teacher of this } \\
\text { lecturer can take a native speaker to give examples in front } \\
\text { of us. So, it will not be a boring class." }\end{array}$ \\
\hline 3 & DEDE & $\begin{array}{l}\text { "I think for the next speech method, the teacher must not too } \\
\text { serious in the teaching-learning process, and the teacher } \\
\text { should give some jokes in order not be boring." }\end{array}$ \\
\hline 4 & DWL & $\begin{array}{l}\text { "I think for the next speech method, the teacher must } \\
\text { practice the way of delivering Speech in front of us with his } \\
\text { body language. The teacher should forbid the students to } \\
\text { bring any kinds of text and note in delivering Speech." }\end{array}$ \\
\hline 5 & GP & $\begin{array}{l}\text { "I think for the next speech method, the lecturer must give } \\
\text { the students more practicum in order that the students can } \\
\text { speak fluently." }\end{array}$ \\
\hline 6 & ITH & $\begin{array}{l}\text { "I think for the next speech method, the teacher must give us } \\
\text { more practicum." }\end{array}$ \\
\hline 7 & NA & $\begin{array}{l}\text { "I think for the next speech method, the teacher must give } \\
\text { more times to deliver the speech minimally thirty minutes } \\
\text { for each student in delivering the speech." }\end{array}$ \\
\hline 8 & NHDN & $\begin{array}{l}\text { "I think for the next speech method, the teacher must be } \\
\text { active and interested in teaching the speech method." }\end{array}$ \\
\hline 9 & NIA & $\begin{array}{l}\text { "I think for the next speech method, there must be a native } \\
\text { speaker who can give us more examples in front of the } \\
\text { class." }\end{array}$ \\
\hline
\end{tabular}




\begin{tabular}{|l|l|l|}
\hline 10 & SH & $\begin{array}{l}\text { "I think for the next speech method, the teacher must be } \\
\text { better in teaching the speech method." }\end{array}$ \\
\hline 11 & TW & $\begin{array}{l}\text { "I think for the next speech method, this a speech method } \\
\text { must be conducted for every semester because it has a short } \\
\text { time if this is just conducted in the sixth semester only." }\end{array}$ \\
\hline 12 & ZH & $\begin{array}{l}\text { "I think for the next speech method, the teacher must care } \\
\text { for the students; he has to know about the students' } \\
\text { condition and do not just focus on the slide presentation." }\end{array}$ \\
\hline
\end{tabular}

The responses to both the questionnaires and the interview led to the main conclusion that students perceived a speech method improved the sixth-semester students' speaking skills, especially in the speaking IV. The answer can see that the percentages of this answer were $100 \%$ (questioners) answer "YES." The respondents perceived that a speech method could improve their speaking skills and increase their vocabularies and confidence. These statements also can be proven in the answer of the interview where eleven (11) respondents answered "YES." In contrast, one (1) respondent out of twelve (12) answered "YES," but she stated that she was lazy to increase her vocabularies in a speech method.

Generally, the sixth-semester students of 2014 A liked the teacher of a speech method, but they just did not like how he taught the speech method because he was too severe in explaining the material that made the students sometimes feel bored. This statement is shown in the answer of the questioners that $92 \%$ of respondents say "YES" on whether the teacher of a speech method taught them very well. At the same time, every student answered based on the interview that they just did not like their teacher of a speech method who was too severe in explaining the material of a speech method without any intermezzo.

Also, all of the respondents argued if a speech method had been becoming an excellent way to be implemented in the speaking IV, but they also said that the lecturer gave a short time during a semester. It can be seen in the answer of the questioners where eight (8) respondents or $67 \%$ answered "YES," while four (4) respondents out of twelve (12) or 33\% answered said "NO." Besides, that statement can be supported by questioner number 15, in which they agreed if a speech method was conducted every semester. The answer is proven in the percentage if $67 \%$ of the respondents answered "YES," while 33\% answered "NO."

Similar research was conducted by (Lutviana 2016); the researcher showed that the implementation of a speech contest was conducted for 15. Each student was asked to deliver the Speech for about 10-15 minutes in front of the audience. The result showed that the students could perform and entertain the audience well. Although none of the students became the winner, the students were motivated to speak better. The difference of this previous study is that the use of speech contests was conducted to improve students' fluency in speaking English, which means the students were forced and motivated by the contest because every student tried to do their best.

In contrast, the implementation of the speech method in the University of Banyuwangi was conducted as part of the Speaking IV subject learning process. Both studies have different implementation and pressure levels. However, both studies could run well that shows the implementation of speech method could finally improve students' speaking skills. 


\section{Conclusion and Suggestion}

From the previous chapter, the respondents perceived that a speech method improved the sixthsemester students' speaking skills at the University of Banyuwangi. Eleven (11) or 92\% of respondents agreed that they improved their speaking skills after joining the speech method.

Besides, the respondents also stated that a speech method in speaking IV enriched the students' vocabularies. The students were forced to deliver their Speech, and some students were allowed to bring text or notes related to the Speech even actually. The teacher said that it would be better to deliver the Speech without bringing any kinds of text.

Besides, using the speech method could improve university students' speaking skills, but it was found that the participants just did not like the way the implementation of the speech method. Therefore, here are some requests for the teachers who want to implement speech method to make the class more attractive:

$\checkmark \quad$ The students requested the teacher of a speech method to not just focus on the presentation slides and make the class more interesting.

$\checkmark$ The students requested to give more exercise of delivering Speech than an explanation of the material.

$\checkmark \quad$ A student requested the Department of English Education to conduct a speech method every semester because the existence of a speech method has a short time during a semester.

\section{REFERENCES}

Burns, A., \& Joyce, H. (1997). Focus on Speaking-North Ryde, N. S. W: National Centre for English Language Teaching and Research.

Lutviana, R. (2016). Speech Contest to Improve Students' Fluency in Speaking. Jurnal Ilmiah Bahasa dan Sastra, 3 (2).

Miranda, M. (2018). The Implementation of Impromptu Speech to Improve Students' Speaking Skill. Banda Aceh: Ar-Raniry State Islamic University of Darussalam.

Suryana. (2010). Metode Penilitian Model Praktis Kuantittif dan Kualitatif. Bandung: Universitas Pendidikan Indonesia. 
Students' Perception of Speech Method toward the University Students' Speaking Skill Ayu Wulandari 